\title{
ÂŞIK TARZı ŞiiR GELENEĞiNDE KALENDERî TÜRü
}

\section{The Kalenderi Genre in the Turkish Minstral Tradition}

\section{Dr. Adem BALKAYA*}

ÖZ

Halk şiirinde şekil ve tür tasnifine yönelik ulaşılabilen ilk eser Ahmet Talat Onay'in “Türk Halk Şiirlerinin Şekil ve Nev'i” adlı eseridir. Bu çalışmayı Hikmet ilaydın'ın “Türk Edebiyatında Nazım" ve Hikmet Dizdaroğlu'nun "Halk Şiirinde Türler" adlı çalışması takip etmiştir. Son yıllara doğru bu çalışmalar artarak devam etmiştir. Her çalışma, türlerin daha iyi anlaşılabilmesi için monografik olarak ele alınması gerekliliğini ortaya koymuştur. Elinizdeki çalışmanın hareket noktası işte bu gerekliliktir.

Çalışmanın giriş bölümünde kalenderîlerin birer şekil adı mı yoksa tür adı mı olduklarını anlamaya yönelik öz olarak halk şiirinde şekil ve tür konusuna değinilmiştir. Çalışma daha sonra iki bölüm halinde tasarlanmış, ilk bölümde kalender ve kalenderî kelimelerinin ne anlam ihtiva ettiği üzerinde durulmuştur. Kalenderi sözcügüu, sözcük anlamı dışında hem bir tarikatın hem de müzikal bir formun adı durumundadır. Bu kısımda bu anlamlar ayrıntılı olarak tartışıımıştır. Çalışmanın ikinci bölümünde bir âşı şiiri türü olarak kalenderiler üzerinde durulmuştur. Önce şiir tasnifleri arasında nerede ve nasıl gösterildiği verilip bu şiirlerin neden kalenderi adı ile anıldığı araştırılmıştır. Daha sonra kalenderi denen şiirlerin şekil özellikleri üzerinde durulmuştur.

Anahtar Sözcükler: Kalenderi, Şekil ve Tür.

\section{ABSTRACT}

"Form and Genre of Turkish Folk Poem" by Ahmet Talat Onay is regarded as the first work in terms of form and genre at folk poem. This work is followed by "Poem at Turkish Literature" of Hikmet ilaydın and "Genres at Folk Poem" of Hikmet Dizdaroğlu. These studies have recently continued to increase. Hence every study makes monographic study necessary in order to understand genres better. This necessity is the starting point of the study in question.

In the introductory part of the study, the subjects of kinds and forms were briefly mentioned as regard to understanding whether Kalenders are kinds or forms. Later on, it was emphasized what the Kalender and words related to it mean. It was also expressed at which fields and in what respects Kalenders, which are names for both sect and a musical form are used. At this part, these meanings were discussed in detail. As for speaking about the second part of the study, Kalenders were emphasized as genre of Aşık poem. Moreover Kalenders were discussed in terms of where and how they are used and then the fact that why they have been called as Kalenders was researched. Finally, poems called Kalenders were studied for their form characteristics.

Key Words: Kalenderi, Form and Genre.

\footnotetext{
* Kafkas Üniversitesi Fen-Edebiyat Fakültesi Türk Dili ve Edebiyatı Bölümü Öğretim Üyesi (Adembalkaya81@hotmail.com)
} 


\section{Giriş}

Âşık tarzı şiir geleneğinde şekil ve tür meselesi son yıllarda ilgi gören bir konu olmasına rağmen hâlâ tartışmalıdır. Özellikle çoğu tasnifte "Aruzlu" başlı̆̆ı ile verilen şiirlerin birer tür adı mı yoksa birer nazım şekli mi oldukları hala netlik kazanmış değildir. En doğru bilgilerin verilebilmesi için her tür/şekil ayrı ayrı çalışılmalıdır. Öncelikle nazım şekli ve nazım türü kavramlarından nelerin anlaşılması gerektiği belirlenmeli ve bu özellikler dikkate alınarak tasnifler yapılmalıdır.

Nazım türünü tanımlarken belirli nazım şekilleri ile yazılan, belirli bir hacmi ve ezgisi olan, kendisine has bağlamda icra edilen, konu bakımından kesin bir ayrım yapılamasa da belirli konular etrafında oluşturulan şiirler diye tanımlayabiliriz.

Nazım şeklini ise türden türe değişmeyen, nazım birimi, ölçü ve kafiye şeması gibi şiiri oluşturan dış özellikleri kesin kurallara bağlanmış olan şiirler şeklinde tanımlayabiliriz.

Özellikle divan şiirinde bu ayrım çok rahat yapılabilmektedir. Söz gelimi kaside bir nazım şeklidir. Kafiye şeması, nazım birimi gibi özellikleri asla değişmez. Na't, tevhid vb. ise şiir türüdür. Na't türü kaside nazım şekli ile yazılır. Halk şiirinde hangi şiirin şekil hangi şiirin tür olduğu konusu tartışmalıdır.

Âşık şiirinde şekil ve tür konusunda iki farklı düşünce olduğunu söyleyebiliriz. Bunlardan ilki âşık şiirinde nazım şeklinin olmadı̆̆ıdır. Bu fikri savunan araştırmacılara göre âşık şiirinde şekil ve tür hemen hemen aynı anlamlara gelen kavramlardır ve hepsi için 'tür' ifadesi kullanılır. Diğer bir düşünce ise koşma ve mâni olmak üzere iki nazım şeklinin olduğu ve diğerlerinin de bu iki ana şekilden türediğidir. Özellikle mâni ve koşma artık neredeyse her araştırmacı tarafından kabul edilen âşık şiiri nazım şekilleri olmuştur. Bunun yanında hala, nazım şeklinin olmadığını savunan araştırmacılar da vardır. Konu ile ilgili görüş bildiren çoğu araştırmacının kabul ettiği tek ortak nokta ise şekil ve tür ayrımı yapılacaksa ezginin de dikkate alınmasıdır.

Ancak şu husus gözden kaçırılmamalıdır. Eğer bütün bir âşık şiiri geleneğine bakılacak olursa divan şiiri içerisinde gördüğümüz birçok nazım şeklinin âşıklar tarafından da sıklıkla kullanıldığı görülecektir. Gazel, murabba, muhammes, müstezat vb. birçok şekil âşıklar tarafindan oldukça fazla rağbet görmüş ve kullanılmıştır. Bu nedenle âşık şiiri için yapılacak tasniflerde bu şekiller de göz önünde bulundurulmalıdır. Hatta kimi şekillerin âşık şiirine kimi şekillerinse divan şiirine aitmiş gibi gösterilmesi de tartışılmalıdır. Öyle ki divan 
şïri nazım şekli olarak görülen kimi şekillerin âşık şiirinden etkilenme ile oluştuğu veya tam tersi bir durum olarak âşık şiirine aitmiş gibi bilinen kimi şekillerin divan şiirinden etkilenme ile oluştuğu söylenmektedir. Örneğin murabba ile koşma nazım şekillerinin birbiri ile benzerliği bu tartışmalardan biridir (Kurnaz ve Çeltik 2010: 176).

Bu kısa bilgiler ışı̆̆ında kalenderî adı verilen şiirleri birer nazım şekli değil de nazım türü olarak kabul etmek gerekir. Zira kalenderîlerin kendilerine mahsus icra yerleri, icra şekilleri, ezgileri vardır. Bu şiirler farklı nazım şekilleri ile oluşturulurlar.

\section{Terimin Kullanım Alanı}

\section{a. Kalender}

Kalenderî kelimesinin menşei üzerinde kesin bir sonuca ulaşılmamış olsa da hemen bütün kaynaklarda Farsça olduğu belirtilir. Ancak, Ahmet Yaşar Ocak, Arapça, Farsça ve Türkçe kaynaklarda bazen Karender ama daha çok Kalender biçiminde kullanılan bu kelimenin, zaman zaman Farsça Kalântar (iri, kaba kimse, Türkçe'de kalantor) yahut Grekçe Kaletoz (aşağı yukarı aynı anlamda)'dan geldiğini ileri sürüldügünü bunun yanında büyük bir ihtimalle Sanskritçe Kalandara (kanun, nizam dışı, düzeni bozan) kelimesinden gelmiş olabileceğinin daha doğru olduğunu vurgular (Ocak 1992: 6-7). Kelimenin kaynağı ile ilgili başka bir görüş de Nihat Azamat'a aittir. İslam Ansiklopedisi'nde Farsça "kalan" sözcüğü ile "ender" ekinin bir araya geldiğini ve "ağır yük taşıyan, ağır yük altına girmiş bulunan" manasında kullanıldığını ayrıca Arapça "ekall" kelimesiyle Farsça "ender" ekinden oluşarak "az, önemsiz" anlamına geldiğini bildirir. Azamat yazısında, Farsça tarihi metinlerde genellikle "rind, ayyâr, derviş" manasında kullanıldığını ama kökeninin tam olarak ne olduğu konusunda görüş birliği olmadığını; öte yandan kalenderin Sanskritçe "töreyi bozan" anlamındaki "kâlândâra"dan Farsça'ya geçtiği ve kabilesinin dışında bir kızla evlenen eski Hint Yogilerine kalender denildiğini, zamanla bu kelimenin Hintli ve İranlı dervişler arasında nefsi terbiye etme bağlamında özel bir anlam kazandığını vurgular (Azamat 1982: 223-224).

Türk Dil Kurumu'nun sözlüğünde; “Gösterişsiz, sade yaşamaktan yana olan, alçak gönüllü kimse, ehli dil, rint; özensiz giyinmiş, kılıksız kimse; yalnız birisi hareketli üst üste konulmuş belirli sayıda silindirden meydana gelen ve düzgün yüzeyli kâğıt üretmek için kullanılan bir makine; özensiz, kılıksız bir biçimde" (http://tdkterim.gov.tr/bts/) şeklinde tanımlanır. Bunlardan başka Ferit Devellioğlu sözlüğünde, "Dünyadan elini çekip başıboş dolaşan derviş; dünyadan elini eteğini çekip her şeyi hoş gören kimse" (Devellioğlu 2006: 484); Kâmûs-1 
Türkîde "dünyadan el çekip, serseriyane gezen derbeder ve laubali derviş, alâik-i dünyevîden müberra ve âlayişlere aldanmaz merd-i hakikatbîn, feylesof" (Sami: 1989: 1080) ; Farsça sözlükte "ilişiksiz, dünyadan alâkayı kesmiş hak ile meşgul olup halka ve âdetlere ehemmiyet vermeyen kimse" diye tanımlanır (Şükun 1196: 1467).

Kelimenin günümüzdeki anlamına bakıldığında "iyi niyetli, sözüne güvenilir, özü sözü bir, ufak tefek şeylere ehemmiyet vermeyen" gibi anlamları ihtiva ettiği görülür. "lyi”" insanı tarif etmek için kullandığımız bu sözcüğün bir zamanlar "sefîl, berdûş, düzensiz bir hayat yaşayan, eğlenceyi seven kimseler için kullanıldığı da bir gerçektir. Bu tür "kötü" tanımlamalar ihtimal ki kalenderî tarikatının zamanla yozlaşarak, düzensiz hayatı tercih edenlerin kendilerini bu isim altında tanıtmalarından doğmuş olmalıdır. Zira dünyaya ehemmiyet vermeme ilkesi kimi kalenderî tarikatı mensuplarınca çok ileri bir seviyeye taşınarak dilenciliğe dönüştürülmüştür. Zaten toplum düzenine aykırı yaşamayı seçmiş, her türlü nizama karşı gelen bir dünya görüşüne mensup bu kişiler, toplum tarafından hoş karşılanmamış ve zamanla yok olmuşlardır.

Bununla beraber aşağıda da görüleceği üzere ilk ortaya çıkış itibariyle oldukça geniş bir coğrafyaya ve büyük bir kitleye yayılma şansı bulan bu dünya görüşü, beğenilen ve özenilen bir tarikat halini almıştır. Bugün dahi kelimeye yüklediğimiz "iyi" vasıfları ifade vizyonu bu durumdan kalmıştır. Özetle dünyaya ehemmiyet vermeyen, rahat bir yaşam sürmeyi ilke edinen kimseler için Kalender, bu ilkeler etrafında oluşturulmuş olan tarikata Kalenderî Tarikatı, bu tarikata mensup kimselere de Kalenderî denmiştir.

\section{b. Kalenderîlik}

Ahmet Yaşar Ocak (Ocak 1992: 5-6) kalenderîliği kabaca, yaşadı̆̆ toplumun her türlü düzenine karşı çıkarak dünyayı kaale almaya değer görmeyen ve bu düşünce tarzını günlük hayat ve davranışlarıyla da açığa vuran tasavvuf akımı olarak tanımlar. Kalenderîliğin mistik temellerinin Hint ve İran ama özellikle Hint mistisizmine dayandı̆̆ını vurgular.

X. asırdan itibaren Orta Asya ve İran'da yaygınlaşan bu tasavvuf cereyanının Maniheizm, Budizm ve Hinduizm gibi eski dinlerin etkisinde kaldığı da söylenir (Kara 1982: 123). Birçok kaynakta Kalenderi tarikatının kurucusu olarak Cemâlü'dîn-i Sâvî gösterilir. Ancak Ocak, ilk kalenderîlerin IX. asırda yayılan Melâmetî felsefesi içinde yetişen müritlerin bazıları olduklarını savunur ve kalenderîliği Cemâlü'dîn-i Sâvî öncesi ve Cemâlü'dîn-i Sâvî sonrası diye ikiye ayırır. Ocak'a göre Melâmetîlik felsefesi içinde yetişen kimi sûfîler daha sonra farklı bir takım hususiyetleri nedeniyle kalenderî diye anılmaya başlanmış ve XII. 
asrın sonu ile XIIl. asrın ilk yarısında sûfiliği tarikat haline getiren Cemâlü'dîn-i Sâvî sayesinde olgunlaşmıştır (Ocak 1992: 16-17).

Kalenderi tarikatının özgün özellikleri arasında oldukça aşırıya giden bir ehl-i beyt sevgisi taşımaları, def, kudüm ve alemleriyle gruplar halinde çeşitli yerleri gezerek tasavvufî anlayışlarını yaymaya çalışmaları, saç, sakal, bıyık ve kaşlarını kestirerek dilencilik etmeleri, kalbe namaz vb. ibadetlerden daha fazla önem vermeleri gibi unsurlar sayılabilir (Cebecioğlu 1997: 425-426).

Abdulbaki Gölpınarlı (Gölpınarlı 1974: 159) en önemli özellikleri olan Çardarb'ın, "çar-tekbir"e yani ehl-i sünnette cenaze namazındaki dört tekbire, bu yolla da ölüme başka bir deyiş olarak da Allah'tan başka her şeyden vazgeçmeye bağlanabileceğini ancak bu durumun örf ve adetlere hatta sünnete isyan manasına geldiğini, bu tür davranışların olsa olsa eski Çin ve Hint dinlerinden kalma adetler olabileceğini vurgular.

Kalenderîlik ilk ortaya çıkışı itibariyle alçak gönüllü olma, büyüklük taslama, gurur ve kibirden kaçınma nefsin isteklerini reddetme gibi davranışlarla takdir toplamış ve beğenilmiştir. Ancak sonradan dünyayı boş vermeyi abartma, çalışmadan geçim temin etme, toplum düzenine aykırı davranma, dinî değerleri yavaş yavaş terk etme gibi hususiyetleri benimseyen müritler veya başka bir dikkatle yukarıda sayılan kimi kötü özellikleri olan kişilerin hayat görüşlerine kalenderîlik maskesini giydirmeleri neticesinde sevilmeyen bir görüş haline gelmesini ve bu düşünce sistemini benimseyenlerin de toplumdan reddedilmesini doğurmuştur. Çoğu araştırmacıya göre Anadolu'daki Alevî-Bektaşî geleneğinin oluşum sürecinde kalenderîlik önemli bir yere sahiptir. Anadolu'nun kültür ve inanç yapısının sentezlenmiş bir çoğul yapıya sahip olmasında sanatın kitleleri yönlendirmedeki etkisinden faydalanılmış ve bir fonksiyonel bağlam olarak kalenderî türü kullanılmıştır.

\section{c. Müzikal Terim Olarak Kalenderî}

Kalenderîleri diğer âşık şiirlerinden asıl ayıran özellikler konudan çok ezgi ve söyleniş tarzlarıdır. Ancak âşıklardan alınacak hava -âşılar daha çok makam kavramını kullanır ancak hava kavramı kullanılmalıdır- isimleri birbiri ile çelişebileceğinden bu konunun müzik eğitimi almış araştırmacılar tarafından incelenmesi daha doğru olacaktır (Bkz. Özarslan 2001).

Mehmet Özbek, Kars, Erzurum, Artvin ve Ağrı illeri çevresinde yaygın olan, özel ezgisiyle yanık bir biçimle seslendirilen bir âşık makamı diye nitelediği kalenderîleri, "saba makamının daha çok âşıklar tarafından kullanılan bir dalı. 
Kalenderî, uzun hava biçiminde okunur; başta ve dörtlükler arasında çalınan bir ayağı vardır"(Özbek 1998: 103) şeklinde tanımlar.

Atınç Emnalar ise sabâ makamının bu türü belirleyen makamsal öğe olduğunu söyler (Emnalar 1998: 402).

M. Zeki Kurnuç da "Manzum eserlerin saz şairi tarafindan bestelenmiş bir musiki ezgisi olmakla beraber genellikle Doğu Anadolu'da icra edilen bir halk şiiri ve musikisidir. Ezgisi bakımından Düz kalenderi, Acem kalenderîsi, Emrah kalenderîsi gibi çeşitleri vardır."(Kurnuç 2005: 2) bilgilerini verir.

Azerbaycan sahası âşık edebiyatında Mürsel Hekimov tarafindan saz havalarına ilişkin hazırlanan cetvelde 58. numarada kalender saz havasından bahsedilir. Bu havanın başka bir isminin de dervişi olduğu, şah perdeden çalındığı gibi özellikleri ile tanıtılır (Hekimov 1987: 64). Bunun yanında yine Hekimov tarafından hazırlanan başka bir eserde Âşık Ekber Ceferov, Âşık Necef, Âşık Talıb, Âşık Hüseyin Saraçlı, Âşık Qedir Veliyev, Âşı Emrah, Âşık Celal Mehemmedoğlu Qehremanov, Âşık Hüseyin Cavan, Âşık Edhem, Âşık Aslan, Âşık Hüseyin Xaloğlu ve daha birçok âşıktan derleyerek hazırladığı cetvellerde kalenderiye rastlanmaz (Hekimov 2004).

Türün şimdilik icrasına denk gelinmediğinden müzikal anlamda bir değerlendirme yapmak oldukça güçtür. Ancak araştırmalardan anlaşıldığı kadarıyla en azından üç ayrı kalenderî havasından bahsedilmektedir. Bunlar Düz, Acem ve Emrah Kalenderîleridir. Ayrıca âşı şiirinden klasik müziğe geçen başka müzik formları da düşünüldüğünde eldeki kalenderîlerin müzikleri üzerine daha detaylı bir çalışma yapılması gerekmektedir.

\section{Kalenderî Türü}

\section{a. Kalenderînin Tasniflerdeki Yeri}

Kalenderiler, hemen her şekil ve tür tasnifinde "Aruzlu nazım şekilleri/ Aruzlu Türküler/Aruzlu Biçimler vb." başlı̆̆ı altında bir nazım şekli olarak tasnif edilirler. Kimi araştırmalarda kalenderîlerin divan edebiyatına mahsus şiirler olduğu dahi söylenir (Tanrıkulu 2000: 46). Hecenin 14'lü kalıbına denk gelen mefulü / mefâîlü / mefâ̂lü / feûlün aruz kalıbı ile oluşturulurlar. Türe dair ilk örneğin kim tarafindan verildiği ve hangi bağlamda ortaya çıtı̆̆ı henüz bilinmemektedir. Bazı araştırmalarda âşık şiirinde IX. yüzyıldan itibaren görülmeye başlandığı belirtilir (Kaya 2007; Ertem 1982) Ancak tarikatın oluşum, yayılma ve etkileme süreci düşünüldüğünde bu tarih daha gerilere götürülmelidir. Kaldı ki elimizde XVll. yüzyıl şairlerinden birçok kalenderî örneği mevcuttur. XX. Yüzyıla gelindiğinde tür neredeyse bitme aşamasına gelmiştir. En 
son İstanbul ve Kastamonu âşık fasıllarında adı geçer. Doğuda Âşık Sümmani ve Âşık Şenlik gibi ustaların şiirleri arasında kalenderîlere rastlanmaz. Son dönemlerde Doğu Anadolu'da yapılan âşık fasıllarında da adı geçmez.

Doğu Anadolu ile neredeyse aynı tür, şekil ve fasılları gördüğümüz Azerbaycan sahasında da çok eskilere ait bir saz havası olarak adı geçer ancak örneklerine rastlanmaz. Son dönem Azerbaycan âşıklarında, Doğu Anadolu âşıklarında da olduğu gibi tür kaybolmuştur.

Vahit Lütfi Salcı, kalenderinin kesinlikle halk şiirine mahsus bir şiir türü olduğu kanısındadır. Salcı́ya göre kimi araştırmacıların türün aruz vezninden alındığını savunmalarına rağmen kalenderi denen şiirlerin heceli oldukları muhakkaktır. Sivas ili Divriki ilçesi Tugut Köyü Danabaşoğlu ailesinden Âşık Veli ile yaptığı görüşmeyi nakleden Salcı, âşı̆̆ın verdiği bilgilerden hareketle kimi kalenderîlerin aldığı değişik adlara da (Düz Kalenderi, Acem Kalenderîsi, Emrah Kalenderîsi) atfen bu savınının doğru olduğunu savunur (Salcı 1940: 233-239). Ancak dikkat edilirse sayılan bu isimler hava isimleridir. Yani herhangi bir kalenderî örneği bu sayılan havaların herhangi birisiyle okunabilir. Bu durum saz havası ile ilgili bir aidiyet yaratabilir; ancak şiir ile ilgili bir aidiyetten bahsetmek güçtür. Buna örnek olarak Azerbaycan sahasında kimi divan şairlerinin 15'li kalıba denk gelen gazellerini divan havalarında okumaları gösterilebilir yahut muhammes havaları içinde Fûzûli'nin "Beni candan usandırdı cefadan yâr usanmaz mi" gazeli sıklıkla okunmaktadır ki ne halk şiirine mahsus bir şiir ve ne de muhammestir.

Kalenderîlerin heceli birer âşık şiiri olduğunu savunan başka bir araştırmacı da Ahmet Talat Onay'dır. Onay'a göre kalenderi denen şiirlerin yazılışına efâil ve tefâil değil şiirlerin okunduğu makam rehber olmuştur. Bununla beraber bu vezin aslen $7+7$ heceden ibarettir, Arapça ve Farsça kelimelerin çok kullanılması arzu veznin tesiri altında kalındığını gösterir. Bir halk veya saz şairine eserinin aruzun filân bahrine uyduğunu söylemek ve üzerinde aruzu uygulamak âşığı hayrete düşürecektir (Onay 1996: 48). Yine Osman Cemal Kaygılı ise kalenderîlerin hem heceli hem de aruzlu olduklarını belirtir (Kaygll 1937: 19).

Kalenderî tarzı şiirlerin âşıklar arasında sınırlı bir alanda varlık göstermesi, örneklerine az rastlanması ve kendisine yaşama firsatı bulamamış olması gibi özellikleri düşünüldüğünde bu türün aruzlu olma ihtimali daha ağır basmaktadır. Elimizde şimdilik heceli olarak bir tek kalenderî örneği bulunmaktadır. Ancak bu şiirin özelliklerini barındıran başka bir şiirin elde olmayışı veya başka bir deyişle bu şiirin bir kalenderî olup olmadığı konusunda doyurucu bir bilgiye sahip olunmadı̆̆ından bu örnek hakkında da bir hüküm 
verilememektedir. Tür şu anda yaşamadığından gerek konu gerek müzik ve gerekse bağlam açısından bir şiirin kalenderî olup olmadığı konusunda peşin hüküm vermek oldukça güçtür. Şimdilik daha önce yapılmış çalışmalarda kalenderî başlı̆̆ı altında verilen şiirlerin kalenderî oldukları varsayılarak bir değerlendirme yapılmaktadır. Türün örneklerini veren âşıklara dikkat edilirse, neredeyse tamamının eğitimli âşılar olduğu görülecektir. Bu durum da türün aruzlu olduğu ihtimalini kuvvetlendirmektedir.

Kalenderîler üzerine görüş bildiren araştırmacılar, tür için her ne kadar doğuyu işaret etseler de doğu fasıllarında kalenderîlerin adı neredeyse hiç geçmez. Bununla beraber kalenderînin âşık fasıllarındaki yerlerine birkaç örnek olarak şu fasıllar gösterilebilir: Kastamonu'daki âşık fasıllarında 12 burca karşılık sayılan 12 tür/şekil şunlardır (Şenel 2007: 24; Ozanoğlu 1940: 24):

1. Taksim

2. Peşrev

3. Divan

4. Semâî (Aruz)

5. Kalenderi

6. Müstezâd

7. Medhiye

8. Satranç

9. Koşma

10. Semâî (Hece)

II. Mâni

12. Destan

Istanbul âşık fasıllarında ise yine şu şekildedir (Günay 1993: 37-38):

1. Bölüm

1. Taksim

2. Divan (Meclisteki tüm âşılar ortaklaşa)

3. Divan (Her âşık ayrı ayrı)

4. Koşma

5. Muamma

6. Milli Türküler

Il. Bölüm

1. Gazel

2. Kalenderi

3. Semai

4. Destan

5. Koşma, Müstazad, Acem Ağzı, Dübeyt, Destan vs.

11l. Bölüm

1. Koşma 
2. Divan

3. Kerbela Destanı

4. Methiye

5. Muamma Çözümü

\section{b. Türe Kalenderî Adının Verilmesi}

Vahit Lütfi Salcı (Salcı 1940: 235), bu şiirlere kalenderi denilmesini halk şairlerini dikkate alarak "Kalender Abdal" veya sadece "Kalender" diye bilinen bir Bektaşi şairinin eserlerini bu tarzda tanzim ettiğini ve diğer şairlerin de şiirlerini oluştururken bu şairin şiir tarzına yaklaştırmalarından ötürü şiirlerine bu adı verdiğini savunur. Söylediklerini ispata yönelik de kimi cönklerde şiirin başına "Gevherî" veya "Katibî” yazdı̆̆ını ancak mahlasından bu şiirin başkasına ait olduğunun anlaşıldığını, şiire bu başlı̆̆ın seçilmesinin de adı geçen şairin şiirine öykünüldüğünden kaynaklandığını söyler.

Onay, isimlendirilmeyi okunmalarındaki hususiyete ve kalenderî tarikat ayinlerinde okunan nefes ve ilahilere benzemesine bağlar (Onay 1996: 195).

Rekin Ertem (Ertem 1982: 122-123) de XIX. asrın sonlarına doğru âşık edebiyatında görülmeye başlayan bir nazım şekli olan kalenderîlerin, kalenderîlere mahsus ayinlerde topluca bir makamla söylenen nefes, nutuk gibi şekillerden çıkmış olabileceğini veya Kalender adlı bir Bektaşi şairinin şiirine benzetilerek yazılan parçalara isim olduğunu ama bunun zayıf bir ihtimal olduğunu vurgular. "Hem hece hem de aruz ölçüsü ile yazılıış kalenderîlerin olması kalenderîlerin kaynağı ile ilgili tereddütleri doğurmuştur. Ya âşıkların on dört heceyle söylediği kalenderiler divan şairleri tarafından hoş karşılanarak bu ölçüye uyan aruz kalıbı ile söylenmiş ya da divan şairlerinin etkisinde kalan kimi âşıklarca divan şiirinden âşık şiirine taşınmıştır. Semai kahvelerinde birkaç kişiyle birlikte söylenmesi kalenderîlerin tekkelerde topluca söylenmesi geleneğinden kalmıştır ki bu da bu şiirlerin kalenderîlikle alakalı olduklarını gösterir. Maskaralık, istihza, alay, tariz, telmih, nükte gibi konuları işleyen ilk kalenderîlere sonraları aşk, hasret gibi konular girmiştir" (Ertem 1982: 122-123).

Kalenderî örneklerindeki konulara ve konuları işleyişe bakılırsa aslında bu şiirlerin bir "tarz" olduğu görülecektir. Sıradan bir gazel, bir murabba veya bir divandan daha hafif, şuh ve şen şiirlerdir. Örneğin kalenderî örneklerinin neredeyse tamamı sekülerdir. Kalender yaşam tarzının şiire yansımasıdır ama bu yansımada toplumsal bir pratiğe denk gelinmez. Hiçbir şeyi dert etmeme, rahat bir yaşam tercihi, dünyayı umursamama gibi görüşlerin şiirdeki karşılığıdır. İddia edildiği gibi birinin şiirine benzeme veya birinin adıyla yaşama gibi bir gayeleri yoktur. Aksi halde bütün kalenderîler bir kalemden çıkmış gibi olmalıydı. Fakat 
"kalenderî bir tarzın" varlı̆̆ı düşünülürse bu hayat görüşünün şiirde kendini bulmasından hareketle bu ismin verilme ihtimali daha ağır basmaktadır. Özetle bu şiirlere kalenderî denmesi kalenderî tarikatının veya müritlerinin dünya görüşünün şiirlerde bulduğu karşılık olarak görülmektedir. Ancak bu dünya görüşünden kasıt bir tarikatın dini işleyişi değil tarikat mensuplarının seküler hayat tarzlarıdır. Hele hele de kalenderîlerin icra bağlamları düşünülürse fasıllarda topluca okunurlar, bu durumun tarikat ayinlerinden kalma bir adet olduğu neredeyse kesin gibi gözükmektedir- bir tarzın adı oldukları ihtimali daha da kuvvetlenir. Ayrıca Azerbaycan sahasında kalender saz havasının diğer adı da dervişi'dir.

\section{c. Kalenderîlerin Şekil Özellikleri}

Kalenderîler nazım şekli değil nazım türüdürler. Bu tür de değişik nazım şekilleri ile icra edilir. Kalenderî tarzı şiirlerin icrasında kullanılan şekiller daha çok divan şiirinde kullanılan nazım şekilleridir. Araştırmalarda kalenderîlerin, gazel, murabba, muhammes, müseddes yahut müstezat biçiminde oldukları (Kaya 2007: 399-400; Dizdaroğlu 1969: 137; Aça vd. 2009: 542, Dilçin 2009: 359) söylense de muhammes ve müseddes şeklinde kalenderî örneği elimizde mevcut değildir. En çok gazel, murabba ve müstezat şekli kullanılmıştır.

1) Gazel şeklinde;

Göster güzelim hüsnüne hayran olayım ben

Firkatte iken diline şâdan olayım ben

Ağyâr ile sohbetler idüp bâde içersün

Lâyık mı görüp hâk ile yeksan olayım ben

Düşürme siyah zülfünü gerdâna dökülsün

Zülfün teline ey perî kurban olayım ben

Ey nâzenînim lûtfun ile iznin olursa

Bir gice girip koynuna uryan olayım ben

Bu Gevherî kulunu derde düşürdün

Bir bûse virüp derdine derman olayım ben (Elçin 1998: 624)

Başka bir örnek;

Kul başına âlemde gelen hükm-i kaderdir Ol hükm-i kader bizlere mîrâs-1 pederdir 
Ben hırsızı hırsız beni görmek ne mümkin

Görmez göze duymaz kulağa sor ne haberdir

Ben kapımı [kitler] yatarım el neme lazım

Çok il şugûlü zevkime gayet leke vardır

Lâ havle velâ kuvvete illâ hüve billâh

Aliyyi'il-azîm mümine her yerde siperdir

Mevtimde müneccim diye mensûbum olur

Taşları cavâhir[dir] anın toprağı zerdir

Yoldan geçen ervâhıma bir Fâtiha versin

Kim görse diye tek şu mezar Dertli mezardır (Düzgün 2011: 198)

2) Murabba Şeklinde;

Sevdim yine bir gamzesi kattal küçücükten

Gafil iken etti bana bir al küçücükten

Ol hâl-i siyeh rûyi ele al küçücükten

Sarmış başına kırmızı bir şal küçücükten

Dîvânesi olduğumuz âyâ nice duydu

Yohsa bu dahi dâma düşüp dâneye uydu

Çok zâhidi bir cübbe vü destâr ile koydu

Kıldı nice sergeşteyi abdal küçücükten

Kûyin dolaşur bendesi çok mest ü hem âguş

Kimisi nazar kerdesidir kimi ferâmûş

Âzârda dil kılmış iken gûşına mengûş

Aklımı diler pâyine halhal küçücükten

Reftâre gel ey serv-i sehî gel göreyim gel

Güller gibi gül pâyine yüzler süreyim gel

Dedim küçücük bûsene cânım vereyim gel

Güldü dedi cânın var ise al küçücükten

Ol nevhevesin eyle fedâ yoluna ser sev

Cevr ü sitem ü kahrını çek tutma siper sev

Bir dilber-i nevresteyi sev Âşık Ömer sev

Bildiğin unutmaz o meh her hal küçücükten (Ergun 1936: 265) 
3) Müstezat Şeklinde;

Bu nazım şekli ile yazılan kalenderîlerin Mefûlü Mefâîlü Mefâilü Feûlün kalıbı ile oluşturulan uzun mısralara mefulü feûlün kalıplı kısa mısralar eklenir ki bu kısa mısralara ziyade, ayak veya yedek denir. Bu halde oluşturulan kalenderîler de Ayakıı Kalenderî veya Yedekli Kalenderî adını alır.

Dilber sana ben gözleri mestan dimedim mi

Fettan dimedim mi

Efgan ederek bende bu giryan demedim mi

Nâlân demedim mi

Meftun olalı sen mehitâbâna gönülden

Ah ne gelir elden

Kaddimi hilal eyledi devran demedim mi

Hicran demedim mi

Sevmez beni yâr niceye dek şâh-1 levendim

Sen kendi efendim

Gel sevdiceğim eyleme bühtan demedim mi

Her an demedim mi

Ermen ne aceb kadr-i visâlinle murada

Bu devr-i fenâda

Eyyâm-1 şerîf Gevherî kurban demedim mi

Ferman demedim mi (Elçin 1998: 625-626)

Yukarıya alınan örnekler aruzun belirli bir kalıbı ile oluşturulan kalenderîleri göstermektedir. Ancak tartışmalardan biri kalenderîlerin aslında hece ölçüsü ile oluşturulduğudur. Şimdilik hece ile oluşturulan kalenderîlere denk gelinmemektedir. Bununla beraber hece ile oluşturulmuş kalenderî örneği olarak Osman Cemal Kaygııı (Kaygılı 1937: 19-20) tarafından aşağıdaki şiir örneği verilmiştir:

Derd ü gam aşk u sevda

Eyledi beni şeyda

O güzelin yoluna

Eyledim canım feda

O güzelin yoluna

Saçım başım yoluna

Taramış kâkülleri 
Atmış sağ u soluna

Taramış kâkülleri Gerdanda fülfülleri

Sanırsın yanağında

Açmış cennet gülleri

Sanırsın yanağında

Küpeler kulağında

Ayda ay yıl, ay yıldız

Mah cemalin mahitap

Şiir 7 heceli dörder mısradan ve zincirleme bir özellikle sıralanmıştır. Bugün hâlihazırda örneği verilmeyen ve daha önceki yıllarda oluşturulmuş ve kalenderî başlı̆̆ ile günümüze aktarılan şiirlerden hareketle bir şiirin kalenderî olup olmadığı konusunda kesin hüküm verilememektedir. Kaygılı şiiri verirken kalenderîlerin şekil özellikleri ile de ilgili bir açıklama yapma gereği duyar ve bu şiirlerin, muhakkak her dörtlüğün üçün mısraının kendinden sonraki dörtlüğün ilk mısraı olması gerektiğini belirtir. Bu durum kafiye örgüsünün de aaba bbcb ccdc dded.. olması anlamına gelir. Kaygılı ayrıca bu durumun şiirde mana ve kafiyeyi bozduğundan da yakınır (Kaygılı 1937: 19).

\section{Sonuç}

Kalender sözcügünün kökeninin kesin olmamakla beraber Farsça veya Sanskritçe olduğu kabul edilir. Dünyaya ehemmiyet vermeme, her türlü nizama karşı gelme, hiçbir şeyi dert etmeme gibi anlamları karşılar. Özellikle XII. ve XIII. yüzyıllarda geniş kitlelere yayılma şansı bulan bir tarikatın da adıdır. Bu tarikatın beslenme kaynakları olarak Maniheizm, Budizm ve Hinduizm özellikle de Hint mistisizmi gösterilir. Aynı zamanda bu dünya görüşü Anadolu'da gelişen AleviBektaşi geleneğinin de hazırlayıcısı durumundadır.

Âşık tarzı bir şiir türü olarak kalenderîler, işte bu tarikat ayinleri ile başlayan bir geleneğin ve bu tarikatın dünya görüşünün, hayata bakışının biraz değiştirilerek şiire yansımış halidir. Seküler konulara ağırlık vermesi, diğer türlere nazaran daha şen daha şuh konuların işlenmesi ve türün bu şekilde isimlendirilmesinde en etkili faktör olarak bu durum gösterilebilir.

Kalenderî örneklerine artık neredeyse hiç rastlanmamaktadır. Bu bir olgunun toplumda kendine yaşama fırsatı bulması ile ilişkilendirilebilir. Toplum özellikle özünden uzaklaşmış tarzda bir hayat görüşünü benimsemez ve hızla 
dışlar. Bu durumdan sanat ve kavramlar da nasibini alır. Ayrıca varlı̆̆ını sürdürememesi şiir özellikleri ile de ilgilidir.

Eldeki örnekler ışığında kalenderî tarzı şiirlerin ölçü olarak aruzlu olduklarını söylemek mümkündür. Bu duruma itiraz eden âşıkların kanıt olarak söyledikleri "kalenderî türleri" aslında birer hava isimleridir. Bu isimlendirmeler genelde bir âşı̆̆ın bir havayı ilk kimden/ nerede duyduysa onun/o yerin adıyla isimlendirmesiyle oluşmaktadırlar. Ayrıca kalenderîlerin icra ortamları da türün ölçüsü ve ortaya çıkışı ile ilgili bilgi vermektedir. Genellikle fasıllarda -ki bu fasıllar İstanbul ve Kastamonu gibi sınırlı yerlerdeki fasıllardır- topluca okunurlar. Bu tarikat ayinlerin kalma bir gelenek ile izah edilebilir. Bunun dışında türün bütün âşıklar tarafından değil de eğitimli âşıklar tarafından rağbet görmesi de bu durumu destekler. Elimizde şimdilik bir tane hecenin yedili ölçüsü ve dörtlükler halinde kalenderî mevcuttur. Ölçü olarak aruz tercihi beraberinde aruzun kullanıldığı nazım şekillerini de getirir. Bu nedenle en çok gazel, murabba ve müstezat şeklinde kalenderîlere denk gelinir.

\section{KAYNAKÇA}

AÇA, Mehmet, Halûk Gökalp, İsa Kocakaplan. Başlangıcından Günümüze Türk Edebiyatında Tür ve Şekil Bilgisi. İstanbul: Kriter Yayınları, 2009

AZAMAT, Nihat. "Kalenderiyye". Türkiye Diyanet Vakfi ìslâm Ansiklopedisi. İstanbul, 2001, Cilt: XXIV.

CEBECiOĞLU, Ethem. Tasavvuf Terimleri ve Deyimleri Sözlüğü. Ankara: Rehber Yayıncılık, 1997. ÇOBANOĞLu, Özkul. Âşık Tarzı Şiir Geleneği ve Destan Türü. Ankara: Akçağ Yayınları, 2000.

DEVELLiOĞLU, Ferit. Osmanlıca - Türkçe Ansiklopedik Lûgat. Ankara: Aydın Kitabevi Yayınları, 2006.

DilçiN, Cem. Örneklerle Türk Şiir Bilgisi. Ankara: Türk Dil Kurumu Yayınları, 2009.

DiZDAROĞLU, Hikmet. Halk Şiirinde Türler. Ankara: Türk Dil Kurumu Yayınları, 1969.

DüZGüN, Dilaver. Dertli Divanı Karşılaştırmalı Metin. Erzurum: Fenomen Yayınları, 2011.

ELÇiN, Şükrü. Gevherî Divânı. Ankara: Atatürk Kültür Merkezi Başkanlığı Yayınları, 1998.

EMNALAR, Atınç. Tüm Yönleri ile Türk Halk Müziği ve Nazariyatı. İzmir: Ege Üniversitesi Basımevi, 1998.

ERGUN, Sadettin Nüzhet. Âşık Ömer Hayatı ve Şiirleri. İstanbul: Semih Lütfi Matbaa ve Kitabevi, 1936.

ERTEM, Rekin. “Kalenderî”. TDEA Devirler İsimler Eserler Terimler. İstanbul: Dergah Yayınları, 1982, Cilt: V.

GÖLPINARLl, Abdülbaki. "Kalenderiye”. Türk Ansiklopedisi. İstanbul: MEB Yayınları, 1974, Cilt: XXI.

GüNAY, Umay. Türkiye'de Âşık Tarzı Şiir Geleneği ve Rüya Motifi. Ankara: Akçağ Yayınları, 1993.

HEKiMOV, Mürsel. Aşıq Senetinin Poetikası, Bakı, 2004.

HEKIMOV, Mürsel. Aşık Şe'rinin Növleri, Bakı, 1987.

ilaydın, Hikmet. Türk Edebiyatında Nazım. İstanbul: İnkılâp Kitabevi, 1961. 
http://tdkterim.gov.tr/bts/ (25.11.2011)

KARA, İsmail. "Kalenderiye". TDEA Devirler isimler Eserler Terimler. İstanbul: Dergâh Yayınları, 1982, Cilt: V.

KAYA, Doğan. Ansiklopedik Türk Halk Edebiyatı Terimleri Sözlügü. Ankara: Akçă̆ Yayınları, 2007.

KAYGILI, Osman Cemal. İstanbul'da Semaî Kahveleri ve Meydan Şairleri. İstanbul: Bürhaneddin Basımevi, 1937.

KURNAZ, Cemal ve Halil Çeltik. Divan Şiiri Şekil Bilgisi. Ankara: H Yayınları, 2010

KURNUÇ, M. Zeki. Erzurum ve Türk Musikisi. Erzurum: Güneş Vakfi Yayınları, 2005.

OCAK, Ahmet Yaşar. Osmanlı İmparatorluğunda Marjinal Sûfîlik: Kalenderîler (XIV-XVII. Yüzyıllar). Ankara: Türk Tarih Kurumu Yayınları, 1992.

OĞUZ, Öcal. Halk Şiirinde Tür, Şekil ve Makam. Ankara: Akçağ Yayınları, 2001.

ONAY, Ahmet Talat. Türk Şiirlerinin Vezni. (Haz. Cemal Kurnaz). Ankara: Akçağ Yayınları, 1996. , Türk Halk Şiirlerinin Şekil ve Nev'i. (Haz. Cemal Kurnaz). Ankara: Akçağ Yayınları, 1996.

OZANOĞLU, ihsan. Aşık Edebiyatı. Kastamonu: Şenkıral Matbaası 1940.

ÖZARSLAN, Metin. "Âşıklık Geleneği İçinde Âşık Müziği ve Kimi Problemler". Erdem Türk Halk Kültürü Özel Sayısı-ll. Mayıs 2001, 13 (38): 399-409

ÖZBEK, Mehmet. Türk Halk Müziği El Kitabı 1 Terimler Sözlügüu. Ankara: Atatürk Kültür Merkezi Başkanlı̆̆ı Yayınları, 1998.

SALCl, Vahit Lütfi. “Kızılbaş Şairleri V”. Halk Bilgisi Haberleri. Ağustos 1940, 9 (106): 233-239.

Sâmi, Şemseddin. Kâmûs-1 Türkî. İstanbul: Enderun Kitabevi, 1989.

ŞENEL, Süleyman. Kastamonu'da Âşık Fasılları Türler/Çeşitler/Çeşitlemeler. İstanbul: Kastamonu il Özel Idaresi Yayınları, 2007.

ŞüKÛN, Ziya. Farsça-Türkçe Lûgat. İstanbul: Milli Eğitim Bakanlı̆̆ı Yayınları, 1996.

TANRIKULU, Nazım İran. Âşıklar Divanı. İstanbul: 2000. 